\title{
The Influence of Creative Self-Efficacy towards Creativity with Job Satisfaction as Intervening Variable at PT. Smile Island Surabaya
}

\author{
Adita Anggarwati, Anis Eliyana ${ }^{1}$
}

\begin{abstract}
:
The study focused on the creative self-efficacy, creativity, and job satisfaction and how these variables influence each other. Job satisfaction acts as the intervening variable for allegedly having influence on the relation between creative self-efficacy and creativity. Creativity is one of the main essential that need to be cultivated in work environment and communicated towards employee in order for the company to develop. The population used in this study is employees of an advertising company specialized in media printing PT. Smile Island Surabaya focus on the division of layout editor with a total of 38 employees.
\end{abstract}

The analysis in this study is using Partial Least Square (PLS) analysis. The result of the study shows a significant influence for some hypothesis with $t$ statistic of 1,96 which are creative self-efficacy influences on job satisfaction with a score of 11,5779, job satisfaction on creativity with a score of 3,4212, and creative self-efficacy on creativity and job satisfaction as an intervening variable in full mediation.

Meanwhile, creative self-efficacy doesn't show a significant influence towards creativity shown evidently with a score of 1,0809 because of different perceptions on creative assessment between supervisor and employee.

Key Word: creative self-efficacy, job satisfaction, creativity

1 Professor, SE., M.Si., Management Department Economics and Business Faculty Universitas Airlangga 


\section{Introduction}

The success of a company's business is supported by various factors, either by organization environment or self-encouragement of the employees. Creativity is the main essence in the development of organization's value. However a creative idea cannot just show up, it needs a thinking process that developed from time to time. Creativity and innovation are two crucial things in the development of a company. Previous studies (Kanter, 1983; Utterback, 1994; Amabile et al., 1996; Tushman and O'Reilly, 1997) proved that creativity can enhance the competitive advantage of the organization in the development of ideas and new practices; and assist in company success.

PT. Smile Island is a company located in Surabaya and running a business in digital printing since 1999. In general PT Smile Island provides services in consulting and solutions about various things such as supplies, printing services, digital printing machine and printing output. Creative employees are needed in many companies especially in advertising companies like PT. Smile Island in which its daily performance is closely related to ideas creation. The creations and breakthrough solutions from the employees need to be observed and supported by PT Smile Island in order to form the individual creative potential of individuals. Creativity facilitates the creation of ideas or products and when this is maximized, it can become a competitive advantage for PT Smile Island. It can help PT Smile Island produces better quality products and organizational development more rapidly than other advertising companies. The respondent of this study is layout editors who is responsible for designing printing publication format, ranging from the texts, photos, and the content based on customer demand. This division was chosen because their daily assignment requires creativity on regular basis such as creation and development of ideas. Moreover, they also should accommodate personal customer demand in which it shows that various creativity ideas are needed in their performance. Therefore each order can be in accordance with the customer's wishes.

Personal factors such as congenial personality, intrinsic motivation, and self-efficacy are some of the elements in the formation of potential individual creativity (Oldham and Cummings, 1996). Bandura (1997: 3) defines self-efficacy as beliefs in one's capabilities to organize and execute the course of action required to manage prospective situations. Related to creativity, creative self-efficacy is the focus in this study. Self-efficacy is an appraisal and a conviction in creative potential in oneself to create and develop ideas and solutions (Diliello et al., 2011). Employees who have high self-efficacy, tend to be more active to explore and to search the creative potential within himself in order to perform a good work as well as to make easier to achieve high job satisfaction. Increasing job satisfaction will affect the performance improvement that indirectly affects individual skills. Individuals who have high job satisfaction will continue compelled to create an idea, ideas, concepts and creative product that will also sharpen their creative skills. 
The resea rch problem in this study was taken from the notion: whether the creative self-efficacy has an influence on job satisfaction of employee PT. Smile Island Surabaya; whether job satisfaction have an influence on the creativity of employees of PT. Smile Island Surabaya; whether creative self-efficacy has an influence on the creativity of employees of PT. Smile Island Surabaya; Whether creative self-efficacy has an influence on creativity and job satisfaction as an intervening variable on the employees of PT Smile Island Surabaya.

\section{Basic Theory and Hypothesis Development}

\section{Basic Theory}

\section{Creativity}

Guilford (1960) found five traits which characterize the ability of creative thinking such as: First, fluency or the ability to produce a lot of ideas. Second, flexibility or the ability to propose various approach or problem solving ideas. Third, authenticity or originality which means the ability to put forth original ideas as a result of his own thinking. Fourth, elaboration or the ability to explain something in detail. Fifth, redefinition or the ability to examine or re-evaluate a problem in a different way and perspective with what is already prevalent.

According to Supriyadi (1994: 8-9) the definition of creativity is differentiated into consensual and conceptual. Creativity definition that represents the consensual and conceptual definition is proposed by Stein (1967) who stated that "The creative work is a novel work that is accepted as tenable or useful or satisfying by a group in some point in time". An understanding of each term is described as follows: the word 'novel' reflects one of the creativity criteria which is a product is considered creative and original even though it is not new and is a combination and reintegration of things that already exists. In other word the existing product put forth to something new. The creative work is in tenable or useful or satisfying ..." it has meaning that creative product must valid, useful and satisfying. Third sentence "... accepted by a group in some point in time" stressing that the outcome of the creative process must be communicated to others, so that the product is experiencing consensual validation.

\section{Creative Self - Efficacy}

Self -efficacy refers to the perception of the individual's ability to organize and implement actions to display certain skills (Bandura, 1986). In Muharrani (2011) there are several supporting theories like Baron and Byrne (2000) who argued that self-efficacy is an individual assessment of ability or competence to perform a task, achieve an objective, and produce something. In addition, Schultz (1994) defined self -efficacy as our feelings about the adequacy, efficiency and our ability to cope with life. 
Creative self-efficacy differs from self-efficacy in general because it focuses on the individual's beliefs about skills and creative potential in him (Chen et al., 2011). Based on the self-efficacy by Bandura (1997), creative self-efficacy is an individual belief in his ability to produce a new work or creative ideas. Amabile (1988) argued that creative performance will be easily achieved when people have the information, knowledge, and skills that support creativity

Creative performance takes time and effort. The need for ongoing diligent so that the creativity can be formed. An individual with a good creative self-efficacy is one of the factors that contribute to the ease of creation of thinking or a creation of creative products. The intrinsic motivation and self confidence that encourage a person to keep thinking and generate a solution in every occasion especially when confronted by work challenges and difficulties.

\section{Job Satisfaction}

Robbins and Judge (2009:113) defines job satisfaction as a positive feeling towards work as a result of the work code evaluation. In line with that definition, Noe et al. (2006:436) also defines job satisfaction as a pleasant feeling as a result a perceptions that the work meets the work's important values. Furthermore, Kinicki and Kreitner (2005: 125) define job satisfaction as an attitude or emotional response to the various aspects of a person's job. This definition gives meaning that job satisfaction is not a single concept. Someone can be satisfied with one aspect of his work and may not be satisfied with one or various aspect of his work. In an almost similar viewpoint, Nelson and Quick (2006:120) states that job satisfaction a positive and pleasant emotional state as a result of a person's working assessment or working experience.

Individual motivation to achieve creativity satisfaction is the focus of this study. Creativity is identical with the creation of a new product or new and original ideas. Someone who managed to transform his creative ideas into a tangible form is not only get the recognition from his surrounding but also a self-satisfaction. Therefore, creativity plays a role as one of the determinants that affect job satisfaction because creativity is a form of aspiration which is used by someone to achieve their achievement. Associated with Maslow's (1973) theory of needs: the need for individuals to express their creativity skills belongs to the level of 'selfactualization' which is the top level in human needs. A satisfaction on creativity is a form of personal fulfilment if the individual consider creativity as an important skill and necessary.

\section{Hypothesis Development}

\section{The effect of creative self-efficacy towards job satisfaction}

According to Phillip and Gully (1997) in Engko (2008), changes in self-efficacy can cause changes in in behavior, especially in the completion of tasks and goals. Bandura (1991) in Chasanah (2008) revealed that individuals with high self-efficacy will reach better work performance because these individuals have a strong 
motivation, a clear objective, stable emotions and the ability to deliver performance and behavior successfully. Then, the hypothesis is drawn as follow:

H1: Creative self-efficacy has significant effect toward job satisfaction on employee of PT Smile Island Surabaya.

\section{The effect of job satisfaction towards creativity}

Job satisfaction will be perceived when the individual has the opportunity to express his creative aspirations in doing their work. Basically, the increase of individual job satisfaction will affect to the performance improvement that indirectly affect the individual skills. Then, the hypothesis is drawn as follow:

H2: Job satisfaction has significant influence on the creativity of the employees of PT. Smile Island Surabaya.

\section{The effect of Creative self-efficacy towards creativity}

Sternberg (2006) in Chuang et al (2010) argue that in order to maximize and develop the creativity, it needs a self-confidence. Creativity without being accompanied by self-confidence cannot develop optimally. Creative self-efficacy helps people to be more creative in a problem solving process therefore they can develop their creative potential. People with high self-efficacy will be tough and like to challenge themselves to continue to have analytical thinking in order to achieve the expected performance. In other words the employees are able to produce creative works by creating attractive designs and incorporate new ideas and its combinations. Then, the hypothesis is drawn as follow:

H3: Creative self-efficacy has significant effect towards creativity of the employees of PT Smile Island Surabaya.

The effect of creative self-efficacy towards creativity with job satisfaction as intervening variable

Bandura (1997) proved that self-efficacy is a stimulus for performance productivity. The employees' job satisfaction in terms of expressing their creative aspiration is one of the factors that affect the relationship of creative self-efficacy towards creativity. The relationship of people's creative self-efficacy towards creativity will take effect positively through positive job satisfaction. Then, the hypothesis is drawn as follow:

H4: Creative self-efficacy has significant effect towards creativity of the employees of PT. Smile Island Surabaya through job satisfaction as an intervening variable.

\section{Research Method}

This study used a quantitative approach using survey method and included in an explanatory study. The type and data source of this study are primary and secondary 
data. Primary data were obtained from interviewees' survey in the field. The questionnaire was the instrument for collecting information which contains list of questions that had been prepared previously. The questions were accompanied by answer choice (enclosed questionnaire). Secondary data were obtained from national and international journal, books about human resources that support the theory used in this study as well as company's documents of PT Smile Island Surabaya.

The sampling technique used in this study was saturated sampling. According Sugiyono (2008), saturated sampling is a sampling technique in which all members of the population were used as a sample. In other words, saturated sample or census in which all members of the population become sample.

Since this study based on creative self-efficacy variable and creativity therefore the population is determined on the basis where creativity had relationship with the performance. Employees who work in the layout division was selected samples for their work in daily basis are related to creation and development of ideas. The collected questionnaires that feasible to have validity and reliability test is as much as thirty eight respondents. Based on the theory, it needs at least $10 \%$ of the population or thirty people as sample of correlation study.

Data processing technique in this study used Partial Least Square (PLS). Partial Least Square (PLS) is a multivariate statistical technique that does comparison between multiple dependent variables and multiple independent variables (Jogiyanto, 2011:55). Measurement model was used to test the validity and reliability of measuring instruments, while the structural model used to test causality. PLS is a reliable tool for testing the prediction model because it can be used for small sample sizes and can be used for a formative and reflective construct. Another reason is because of the PLS can be used for the theory development.

\section{Results and Discussion}

Having collected data from questionnaires, the results were analyzed to determine the validity and reliability of each variable. Variables considered valid if it fulfilled the loading value measurement scale that is a minimum of 0.7 (Chin, 1998 in Ghozali, 2008: 24). The result showed that all indicators from creativity, creative self-efficacy and job satisfaction variables were valid. Reliability cab be tested through composite reliability and Cronbach alpha above 0.7 (Ghozali, 2008: 43). All variables in this study were proved to be reliable. Those variables are creativity, creative self-efficacy and job satisfaction.

Table 1. Inner Model Analysis Result (Structural Model)

\begin{tabular}{|c|c|c|c|}
\hline Relationship & $\begin{array}{c}\text { Regression } \\
\text { Coefficient }\end{array}$ & t statistics & R square \\
\hline CSE $\rightarrow$ Job Satisfaction & 0,7244 & 11,5779 & 0,5247 \\
\hline
\end{tabular}




\begin{tabular}{|c|c|c|c|}
\hline CSE $\rightarrow$ Creativity & 0,1894 & 1,0809 & \multirow{2}{*}{0,5685} \\
\cline { 1 - 3 } $\begin{array}{c}\text { Job Satisfaction } \rightarrow \\
\text { Creativity }\end{array}$ & 0,6054 & 3,4212 & \\
\hline
\end{tabular}

Table 1 shows the influence of creative self efficacy, creativity and job satisfaction. Based on the table, it shows that the R square value of creative self efficacy towards job satisfaction is at 0.5247 or $52.5 \%$. This means that the level of creative selfefficacy can be explained by job satisfaction, while the remaining $47.5 \%$ by other variables that were not examined.

The influence of creative self efficacy towards creativity and job satisfaction had value of 0.5685 or $56.8 \%$, while the remaining $43.2 \%$ was influenced by other variable that was not examined

The relationship between the tested constructs with t statistic showed the result of regression coefficient on influence of creative self-efficacy (X) towards job satisfaction $(Z)$ is positive at 0.7244 . The coefficient is positive when the higher creative self-efficacy, the higher job satisfaction. Statistical $t$ value of $11.5779>t$ table value of 1.96 indicated that creative self-efficacy have a significant effect on job satisfaction. From this result, the first hypothesis (H1) was accepted. It means that Creative self-efficacy had significant effect towards employees' job satisfaction of PT. Smile Island Surabaya. People's belief of creative self-efficacy in themselves will help them to achieve better performance because they had strong motivation, clear objective, stable emotions and the ability to perform successfully on activity or behavior.

In accordance to an analysis conducted by Bono (2001) and Engko (2006) it was said that when the employees have good performance and achieve their target, indirectly, they experienced high job satisfaction as well. Job satisfaction will be achieved when supported by intrinsic motivation (creative self-efficacy), extrinsic motivation (work environment, relationship with colleagues) as well as the people and organization characteristics. It can be concluded that these factors influenced people's job satisfaction level and become a success determinant. In accordance with Ingleheart (1990) stated that one's satisfaction can be achieved when there is an intersection between aspiration and individual achievement.

The regression coefficient value of the effect of job satisfaction $(\mathrm{Z})$ towards creativity $(\mathrm{Y})$ is positive at 0.605 . The coefficient is positive when the higher job satisfaction, the higher creativity. $T$ statistic value of $3.4212>t$ table value of 1.96. It indicated that job satisfaction (Z) significantly affect creativity (Y). Based on this result, the second hypothesis $(\mathrm{H} 2)$ is accepted in which the job satisfaction had significant influence on the creativity of employees of PT Smile Island Surabaya. The increasing of individual's job satisfaction would affect to the increasing of individual's performance in which it indirectly affect the individual's skill. A person who managed to turn his creative ideas into a tangible form, not only will get 
recognition but also a sense of satisfaction in oneself. Therefore, people will continue to encourage creating an idea, ideas, creative concepts and products that will also sharpen their creative skills.

The regression coefficient value of the effect of creative self efficacy $(\mathrm{X})$ towards (Y) is positive, it is at 0.1894 . The coefficient is positive when the higher creative self efficacy, the higher creativity. T statistic value of $1.0809<\mathrm{t}$ table value of 1.96 . It indicated that creative self efficacy $(\mathrm{X})$ did not have significant effect towards creativity (Y). Based on this result, the third hypothesis (H3) did not accept since the creative self efficacy did not have significant effect towards creativity of the employees of PT Smile Island Surabaya.

Based on the analysis calculation, creative self-efficacy only had indirect influence towards creativity, while its direct effect is not significant. The assessment on creative self-efficacy of the employees of PT Smile Island which is positive did not ensure the higher creativity potential. The employees' creativity was rated by the supervisor as a leader and performance supervisor and were not by the employees themselves. This was done because the supervisor is a person who has knowledge and information to assess employees' creativity so that the supervisor will determine whether each employee has met the standards and criteria of creativity that was expected by PT Smile Island Surabaya. Creativity according to the employees has different meaning according to the company because creativity on performance will depend on the leader parameter. Therefore, it can be concluded that creative selfefficacy did not have significant influence towards creativity since there was a different perception of creativity between employees and the supervisor.

The fourth hypothesis (H4) stated that creative self-efficacy has significant influence towards employees' creativity of PT Smile Island Surabaya through job satisfaction as an intervening variable. According to Baron and Kenny (1986) in Frazier et al. (2004) they stated that to prove that there is an effect of mediation (indirect effect or intervening), therefore the evaluation was done to the following criteria:

a. The effect of independent variables on the dependent variables is not significant (without mediator variable/ intervening) or significant by evaluating the next criteria.

b. The effect of independent variables on the intervening variables to be significant.

c. The effect of intervening variables on the dependent variables to be significant.

d. If the effect of independent varibales on the dependent variables are significant with the intervening variables, it is called partial mediation or if the effect of independent variables are not significant with the intervening variables then it was called a full mediation.

The results showed that creative self-efficacy $(\mathrm{X})$ has no significant effect on employee's creativity (Y), but had a significant effect on job satisfaction (Z) as an intervening variable, moreover job satisfaction as an intervening variable 
significantly influence employee creativity $(\mathrm{Y})$. Therefore in accordance to Baron and Kenny (1986), in Frazier et al. (2004), it indicated a full mediation condition because creative self-efficacy did not influence directly towards employees' creativity. It means that the fourth hypothesis which stated that creative self-efficacy has significant influence on the creativity of PT Smile Island' employees through job satisfaction as an intervening variable is accepted.

Positive and significant effect of creative self-efficacy variables in creativity through job satisfaction showed that job satisfaction was supporting variable which indirectly affect the success of creative self-efficacy towards employees' creativity.

Creative self-efficacy will affect the creativity when employee satisfaction has been achieved. Job satisfaction has an impact on the success of the formation of individual's creativity. This was supported by the indicators of job satisfaction variables in which each of them had connection to the employees' freedom in developing creativity either through internal or external support so that the employees had space and opportunity to develop in the company. Gong et al. (2009) stated that the process of job satisfaction will direct the workers to achieve a certain competence so that when the creative self-efficacy, an internal drive of a person, synergies with job satisfaction, the external factor which is organization's environment, will affect the creativity of employees if the relationship between two variables were positive. It could be said that the positive perceptions of job satisfaction is an influential variable in the formation of creative self-efficacy towards creativity to be harmonious. If the job satisfaction is high and has been fulfilled, creative self-efficacy in turn affect indirectly to the creativity skills of the employee.

\section{Conclusion}

In conclusion, there are three hypotheses in this study that were accepted as true. Those are: the first hypothesis ( $\mathrm{H} 1)$, the second hypothesis $(\mathrm{H} 2)$, the fourth hypothesis (H4), while the third hypothesis (H3) was not accepted. Based on the result of hypothesis testing, it was proved that there were relationship where each variables are interrelated and influence each other with exception of creative selfefficacy towards creativity. The positive result of creative self-efficacy showed that the employees had confident about the ability of creative potential in themselves. This means that the employees of Pt Smile Island actually can be optimized in creating and applying the ideas into a tangible form. However, their belief in their self-ability was not enough, they needed the support from the company so that the employees previously could fulfill sense of job satisfaction towards creativity therefore creative self-efficacy can affect directly towards creativity. 


\section{References}

Amabile, T.M. (1988). A Model of Creativity and Innovation in Organizations. In B.M. Staw \& L.L. Cummings (Eds.), Research in Organizational Behavior, 10: 123-167.

Bandura, A. (1997). Self-efficacy: The exercise of control. New York: Freeman.

Chasanah, Nur. 2008. Analisis Empowerment, Self-Efficacy dan Budaya Organisasi terhadap Kepuasan Kerja dalam Meningkatkan Kinerja Karyawan (Study Empires pada Karyawan PT. Mayora Tbk. Regional Jateng dan DIY). Tesis tidak diterbitkan. Semarang Magister Manajemen Universitas Diponegoro.

DiLiello, Trudy C. dan Jeffery D. Houghton. (2008). Creative Potential and Practiced Creativity: Identifying Untapped Creativity in Organizations. Blackwell Publishing. 17 (1): 37-46.

Gong, Y. et al. (2009). Employee Learning Orientation, Transformational Leadership, and Employee Creativity: The Mediating role of Employee Creative Self-Efficacy. The Academy of Management Journal. 52(4): 765-778.

Jogiyanto. (2011). Konsep dan Aplikasi Structural Equation Modeling Berbasis Varian dalam Penelitian Bisnis. Yogyakarta: Unit Penerbitan dan Percetakan STIM YKPN.

Kinicki, Angelo dan R. Kreitner. (2005). Organizational Behavior Key concepts skills and best Practice. New York: Mc Graw-Hill.

Muharrani, T. (2011). Hubungan antara Self-Efficacy dengan Self-Regulated Learning pada Mahasiswa Fakultas Psikologi Universitas Sumatera Utara. Skripsi tidak diterbitkan. Medan Fakultas Psikologi Universitas Sumatera Utara.

Nelson, D.L., and J.C., Quick. (2006). Organizational Behavior Foundations Realities and Challenges. United States of America: Thompson South Western.

Robbins, S.P, dan T.A Judge. 2009. Organizational Behavior. United State of America, New York: Pearson Prentice Hall.

Supriadi, Dedi. (1994). Kreativitas, Kebudayaan \& Perkembangan Iptek. Bandung: Alfabeta

Stenberg, Robert J. (2006). The Nature of Creativity. Lawrence Earlbaum Associates, Inc. 18 (1): 87-98.

Sugiyono. (2008). Metode Penelitian Bisnis. Edisi kedua belas. Bandung: Alfabeta

Sumanto, (1995). Metodologi Penelitian Sosial Pendidikan: Aplikasi Metode Kuantitatif dan Statistika dalam Penelitian. Yogyakarta: Andi Offset.

Zimmerman, Barry J. (2000). Self-Efficacy: An Essential Move to Learn. Contemporary Educational Psychology. 25: 82-91. 